\title{
Relying on weak governments: Austrian trade unions and the politics of smoothed dualization
}

\author{
Philip Rathgeb ${ }^{1, *}$ \\ 1 Department of Politics and Public Administration, University of Konstanz, Germany \\ * E-Mail: philip.rathgeb@uni-konstanz.de
}

\begin{abstract}
Austrian political actors have improved the protection of outsiders by expanding the coverage of labour rights, social security, and active labour market policy spending in the past two decades. The article attributes these 'solidaristic' traits of Austrian labour market policy change to the persistent reliance of weak governments on trade union support in the mobilisation of a durable consensus. When governments are internally divided and prone to reform deadlocks, they face a powerful incentive to share policy-making authority with the social partners. Despite a significant decline in power resources, the Austrian trade union confederation has therefore remained influential enough to compensate outsiders for growing economic uncertainty on a volatile labour market. To substantiate this claim empirically, the article draws on primary and secondary sources as well as interview evidence with policy-making elites.
\end{abstract}

\section{Keywords}

Austria, dualization, governments, labour market policy, public policy, trade unions, social partnership

\section{Angewiesen auf schwache Regierungen: Österreichische Gewerkschaften und die Politik der moderaten Dualisierung}

\section{Zusammenfassung}

Österreich erweiterte in den letzten zwanzig Jahren den Versichertenkreis des Arbeits- und Sozialrechts sowie aktive Arbeitsmarktpolitikausgaben zugunsten von „Outsidern“, d.h. atypisch Beschäftigen sowie erwerbsarbeitslosen Lohnabhängigen. Der Artikel führt die solidarischen Kennzeichen österreichischer Arbeitsmarktreformen auf inhaltliche Zugeständnisse politisch schwacher Regierungen an die Gewerkschaften zurück. Wenn Regierungskoalitionen wie in Österreich intern gespalten und anfällig für Reformblockaden sind, haben sie einen starken Anreiz, die Sozialpartner zur Konsensmobilisierung in den Reformprozess miteinzubeziehen. Trotz eines erheblichen Machtverlusts blieb damit der österreichische Gewerkschaftsbund einflussreich genug, um Outsider für eine gewachsene ökonomische Unsicherheit auf einem volatilen Arbeitsmarkt zu kompensieren. Um dieses Argument empirisch zu untermauern, greift der Artikel auf Primär- und Sekundärquellen sowie Interviewevidenzen mit politischen Entscheidungsträgern zurück.

\section{Schlüsselwörter}

Österreich, Arbeitsmarktpolitik, Dualisierung, Gewerkschaften, Politikgestaltung, Regierung, Sozialpartnerschaft

\section{Acknowledgements}

I want to thank all of my interviewees without whom this research would not have been possible.

The author has declared that no competing interests exist. 


\section{Introduction}

Rising inequality in labour markets and welfare has become a growing concern of the comparative study of advanced capitalist political economies. The problem of inequality is particularly acute for the growing number of atypical and unemployed wage earners: the so-called 'outsiders'. Unlike 'insiders' on permanent and full-time employment contracts, their precarious attachment to the labour market often implies a lack of adequate coverage in job security, social security, and training arrangements. Political actors, however, can shape the nature and degree of insider-outsider divides through democratic state interventions in different ways (Emmenegger et al. 2012). While the neoliberal paradigm shift in the functioning of national models of capitalism points to a general expansion of market mechanisms and economic inequality over time (Streeck 2009; Baccaro/Howell 20II), the political practise of liberalisation at the national level has resulted in divergent distributive outcomes for outsiders (Thelen 2014). Therefore, it can be reasonably argued that the common liberalisation of post-war capitalism did not rule out variation in the reform trajectories of national welfare states, nor did it imply convergence in the redistributive capacities of public policy regimes.

One interesting example of this lack of convergence can be seen in the case of Austria. Declining coverage rates to the detriment of outsiders would be the most likely distributive outcome produced by this Conservative-Continental regime prototype in a post-industrial context (Iversen/ Wren I998; Scharpf 2000). Perhaps unsurprisingly, recent debates indeed view the Austrian political economy against the backdrop of a German-like dualization that shifted the burden of economic adjustment to outsiders of the service sector (Palier/Thelen 20IO; Hassel 20I2; Thelen 20I4). Yet, the reality of the Austrian liberalisation path was quite distinct from that of Germany. Despite similar historical and institutional legacies, Austrian political actors did not emulate the German adjustment path of pronounced dualization like other cases among the Conservative-Continental welfare regime type. Instead, the liberalisation of Austrian capitalism entailed selective elements that ran directly counter to the reinforcement of institutional status divides. A relatively limited share of temporary and involuntary part-time contracts on the one hand, and an expanded coverage of the social insurance on the other, perhaps best illustrate the distributive outcomes of 'smoothed dualization' within the historically evolved institutional constraints of a Conservative-Continental welfare regime (Bock-Schappelwein/Mühlberger 2008; Eichhorst/Marx 2OI2; Fervers/Schwander 2015).

The findings I present below draw on the empirical assessment developed by Obinger et al. (2012) that Austria may be considered a case of smoothed dualization. In the area of labour market policy, this claim refers to a set of in- stitutional changes that (i) homogenised the entitlement conditions for severance payment (Abfertigung neu), (ii) extended the coverage of the social insurance, and (iii) expanded active labour market policy (ALMP) spending; that is, policies enhancing the protection of outsiders. Recent comparative studies lend additional credibility to the claim that Austrian labour market policy change has been more 'solidaristic' relative to similar Conservative-Continental welfare states such as Belgium, Germany, France, and the Netherlands (Eichhorst/Marx 2012; Fervers/Schwander 2015). Even though the Austrian politics of labour market adjustment have been by no means free of the broad neoliberal trend towards the re-commodification of labour (Atzmüller et al. 20I2; Fink/Krenn 20I4), the reform of labour market policy has also been used to extend social entitlements to workers on the margins of the labour force.

This article is an inquiry into the reasons why Austrian political actors enhanced the social protection of outsiders despite tightened fiscal constraints and neoliberal assaults from the political right. It argues that the crucial reason why Austria deviated from the German-like path of pronounced dualization was the persistent influence of the Austrian trade union confederation, the ÖGB (Österreichischer Gewerkschaftsbund), on the policy-making process. It is clear that Austrian governments at various points in time actively sought to overcome the veto power of the ÖGB in the interest of unilateral fiscal consolidation (Tálos/Kittel 200I; Obinger/Tálos 2006). Yet, in the area of labour market policy, they lacked the autonomous reform capacity necessary to reject a process of negotiated adjustment that would include unions. This weakness of Austrian governments, I claim, was necessary for the ongoing influence of the ÖGB on the policy-making process, which caused precisely the 'solidaristic' elements that define the reform trajectory of smoothed dualization.

The dominant government constellation in the neoliberal era has been that of a grand coalition between two ideologically divided and similarly strong parties. Faced with severe economic challenges, their reform capacity was constrained by intra-coalitional divisions, which gave them strong incentives to delegate policy-making authority to a labour-inclusive 'social partnership' (Sozialpartnerschaft). The 'solidaristic' elements of smoothed dualization have therefore not been a product of partisan reform ambitions. It instead resulted from trilateral negotiations between employers, unions, and the state. Elections play little role when governments are notoriously divided and draw on close ties to well-established social partners. We would expect this negotiated reform process to open up opportunities for organised labour to ex- 
tract concessions from the state. Of course, the character of and trade-offs involved in that political exchange changed over time, but the involvement of unions remained indispensable for this process.

In contrast to employers, Austrian trade unions had a strong stake in the protection of outsiders. The growth of temporary 'atypical' workers exercised pressure on the prevailing labour and social security regulations of their core membership. This competitive pressure was most strongly felt by workers in the low-value-added service sector. In a labour movement where decisions are made by the confederal elite, precisely the demands of these workers gain stronger attention than in decentralised labour movements where the interests of the powerful manufacturing unions often prevail (Hassel 20I2; Thelen 20I4). With a high level of labour unity, union leaders in Austria could use their policy-making influence to enhance the social protection of outsiders, and not only a shrinking core of insiders.

That the influence of organised labour was not endemic to institutional and cultural legacies of Austrian post-war corporatism was powerfully demonstrated by the formation of a strong government from 2000 to 2006. Drawing on a high level of ideological cohesiveness, the ÖVP-FPÖ coalition was indeed able to impose its policy preference on unions in a range of issues, especially old-age pensions (Obinger/Tálos 2006; Baccaro/Simoni 2008). In the area of labour market policy, however, the FPÖ blocked significant parts of the ÖVP's agenda to reinforce status divides. In response, the ÖVPFPÖ coalition fell back on trilateral negotiations with the social partners at some points in time (see also Afonso 20I3). Intra-coalitional divisions were therefore necessary for the absence of unilateral reform processes that would have excluded the one single actor that incorporated the interests of outsiders in its political priorities: the unions.

My findings call into question the labour dualism theory advanced by David Rueda (2007), which attributes growing insider-outsider divides to the political preference of union movements in alliance with socialdemocratic parties. In essence, his account conflates trade unions with 'insiders' that resist attempts to enhance the material situation of 'outsiders' in order to defend their own privileged status quo. This is, as I will show, inaccurate in the case of Austria, because here the mobilisation of political support for outsiders was perfectly compatible with the interest representation of insiders. But the preferences of unions are by no means causally determinative due to a shift in the balance of class power from labour to capital in the neoliberal era. My argument therefore emphasises the political opportunities unions face when governments are weak. Under conditions of weakness, governments are more responsive to the demands of unions, because they need sup- port from extra-parliamentary actors in the pursuit of consensus mobilisation.

The article proceeds as follows. First, I develop an argument about how the presence of weak governments allowed Austrian unions to remain influential in the policy-making process to the benefit of outsiders. I then demonstrate my argument through process-tracing of labour market reforms from the early I990s to the early 2010 , using evidence from primary and secondary sources as well as semi-structured interviews conducted with policy-making elites. In the conclusion, I discuss the main findings and implications of this case study.

\section{Organised Labour and Governments in Austria}

The Austrian labour movement rests on a nationally distinct cooperation between two different interest organisations: the Chamber of Labour (BAK) on the one hand, and the Austrian trade union confederation (ÖGB) on the other. The BAK represents the whole workforce due to mandatory membership in corporatist parity bodies such as the social insurance and the public employment service. By contrast, the ÖGB relies on voluntary membership and possesses the legal monopoly to conclude collective agreements, but unites with the BAK in advancing the interests of labour within corporatist parity bodies. That one and the same person often holds leadership positions in both interest organisations fosters the popular perception of a united 'labour block' in Austrian politics. In fact, however, there is a clear division of responsibilities in the political process: the ÖGB determines the political priorities, whereas the BAK delivers the political expertise to achieve these priorities in the industrial and political arenas (Traxler/Pernicka 2007, 223).

A recent finding in the dualization literature is the recognition that encompassing and centralised unions are better able to mobilise political support for outsiders than small and decentralized unions (Palier/Thelen 20IO; Thelen 20I4; Gordon 2015). First, encompassing unions organise a higher share of outsiders, thereby directly incorporating their demands into the interest formation process. Second, centralised unions prevent the formation of particularistic policy priorities, because the confederal elite gives voice to affiliates with lower membership rates. Moreover, administrative roles in labour market policy provide unions with strategic stakes in the protection of the unemployed (Clegg 2012).

The ÖGB forms part of the five most inclusive union confederations in the OECD due to its unmatched levels of concentration and centralisation (Gordon 2015). Its clear political mandate at the confederal level broadens the representational scope of the union movement by 
incorporating the political demands of the less organized service sector in the interest aggregation process, thereby empowering them vis-à-vis their more organised counterparts in the manufacturing sector (Gordon 2015, 90-9I; see also Thelen 20I4). Concentration and centralisation may therefore, at least to some extent, compensate for the incredible shrinking of the ÖGB's membership rates from 63 percent in 1970 to currently a mere 25 percent in the scope of labour representation. The capacity to shift interest concentration to the highest level sets the ÖGB apart from the classical sectoral model of German unionism. While also displaying a unitary structure, the German union confederation (DGB) lacks the institutionalised hierarchies to overcome cross-sectoral divides in public policy-making (Heinisch 2000, 76). Unlike the ÖGB, the weak authority of the DGB therefore underpins an unequal distribution of power between different member unions, which favours a sectoral union framework and co-determination at the plant level.

Labour unity allowed for an inclusive representational focus when employers discovered the usage of atypical employment contracts as a way of boosting flexibility and cost competitiveness. The ÖGB pursued a policy of undermining intra-labour competition between 'regular' and 'atypical' workers by demanding an extension of prevailing labour protections and social security arrangements to those workers who lack coverage in these respects. In a Conservative welfare regime, the enhanced social protection of outsiders helps union confederations to re-gain bargaining power vis-à-vis employers, protect their core members from the low-wage competition of 'atypical' employment contracts and reach out to workers at the margins of the labour force. That said, the earnings-related nature of benefit entitlements in an age of permanent austerity sets institutional constraints on attempts to improve the social security of outsiders.

The formation of inclusive union preferences, however, is not sufficient for a successful compensation of outsiders for growing economic uncertainty, because the gradual decline in union power weakened the assertiveness of labour in the policy-making process. An increase in unemployment rates in tandem with declining membership rates in an age of capital liberalisation refers to this shift in the balance of class power from labour to capital. A unilateral reform strategy against the interests of unions has therefore become less risky for the electoral fortune of national governments. A growing amount of literature documents the declining capacity of unions to resist neoliberal reform ambitions of partisan policy entrepreneurs (Baccaro/Howell 20II; Culpepper/Regan 2014; Hassel 2015). But governments cannot impose any agreement on unions, when their own reform capacity is constrained by intra-coalitional divisions. This weak- ness provides governments with a political incentive to trade policy concessions for union support in the mobilisation of a durable consensus.

\section{Weak governments and union influence}

The core argument of this article is that the presence of a weak government is an important condition under which trade union confederations may retain political influence despite a decline in power resources. Weakness, in our context, refers to a low level of autonomous reform capacity, making governments unable to pursue a unilateral reform strategy that would exclude unions. Under this condition of weakness, the delegation of policy issues to tripartite policy forums helps pre-empt open conflicts and move public attention away to depoliticised elite negotiations. In that sense, union confederations are not mere veto players that can block the reform ambitions of governments. They can also help overcome intra-coalitional divisions through cooperation with employers. The literature of social pacts underlines this mechanism by showing that weak governments are more responsive to the demands of union confederations, because they require support from organised interests in the design, implementation, and legitimisation of economic reforms (Baccaro/Simoni 2008; Afonso 2013; see also Knotz/Lindvall 2015). This is especially the case in the Austrian context, where the social partners' organisational power gives both sides of the class divide a high level of autonomy vis-à-vis pressure from below, which allows for mutual high-trust relations and problem-solving capacity through informal 'gentlemen's agreements' (Heinisch 2000).

One way that governments become weak is through intra-coalitional divisions between ideologically opposed and similarly strong parties. The Austrian grand coalition instructively demonstrated this type of weakness, given that its recognition for the necessity of consensus went hand in hand with mutual reform blockages in the past three decades. First, the challenges posed by the neoliberal era reinforced open distributive conflicts and put an end to the positive-sum game of the booming 'golden age' post-war economy (Tálos/Kittel 200I). Naturally enough, negotiations around sharing the costs of fiscal consolidation between two historically divided camps hardened the political fronts. Second, the relatively balanced distribution of parliamentary seats implied that both parties have been powerful enough to block each other, even though the SPÖ has always been somewhat stronger than the ÖVP in the period of investigation (Obinger 2002). Third, both parties came under growing pressure from the rise of the Green Party and the FPÖ, since the grand coalition partners have almost continuously lost vote shares over the past three decades. We would expect all these factors to challenge the 
ability of a grand coalition to achieve a political consensus around controversial issues.

Close institutional and personal linkages between the two historical major parties and the social partner camps facilitated the delegation of policy-making authority to a labour-inclusive social partnership. Vertical coordination in public policy usually takes place between the SPÖ and BAK-ÖGB on the one hand, and the ÖVP and WKÖIV on the other. The Austrian Economic Chamber (WKÖ) is the counterpart of the Austrian Chamber of Labour (BAK) in representing every employer due to mandatory membership. ${ }^{I}$ In this highly integrated and corporatist 'small state' environment (Katzenstein 1984), the SPÖ has not only established close personal and institutional ties to the ÖGB, which are important for union leaders to influence the legislature. The SPÖ has also been willing to grant significant agenda-setting capacity to socialdemocratic union elites, because the latter can draw on the micro-level information of constitutionally entrenched works councils and the macro-level expertise of the resourceful BAK. Information and expertise are thus important tools deployed by the ÖGB to influence the policy-making action of the SPÖ. Taken together, the interest organisations of labour not only reflect an informal veto player against unilateral reform initiatives of SPÖ-led governments, but also act as a think tank for the party leadership.

But my argument about weak governments extends to parties of the left as well as the right. The formation of a centre-right coalition between the ÖVP and the FPÖ from 2000 to 2006 suggests a higher ideological cohesiveness relative to previous grand coalitions (Müller/ Fallend 2004). Yet, in the area of labour market policy, the neoliberal agenda driven by the ÖVP came under strain from prolonged internal turmoil in the FPÖ. The overwhelming problem for the FPÖ as a governing party was how to reconcile the ideological tension between two opposing wings: the market-liberal government team on the one hand, and the populist grassroots wing on the other (Luther 2003). While sharing the ÖVP's antiunion stance, the electoral success of the populist grassroots wing around Jörg Haider rested on its appeal to the social demands of blue-collar workers. Faced with this intra-partisan tension, the centre-right coalition had to fall back on the social partners to achieve a durable political consensus at some points in time (Afonso 20I3). With the onset of the Great Recession and the return of another grand coalition, the stage was finally set for a veritable revival of Austrian social partnership (Tálos 2008). The next section will show that the prevalence of weak governments created the necessary opportunity for unions to extract concessions for outsiders.

I Unlike the WKÖ, the Austrian Federation of Industries (IV) represents large industrial companies, but does not form an official part of the Austrian social partnership in corporatist state bodies.

\section{The Politics of Smoothed Dualization in Austria}

The core economic problem faced by successive Austrian governments of the I990s was reducing public debt for successful accession to the European Economic and Monetary Union (EMU). Declining economic growth and increasing unemployment rates translated into rising annual public deficits (5.8 percent in 1995), while the debt ratio surpassed the Maastricht threshold of 60 percent in 1993. The structural impetus of rising public debt during the politics of EMU adjustment constrained the policy choices of the ÖGB and provided the WKÖ with an opportunity to push for a shift to orthodox fiscal adjustment. The politics of EMU adjustment culminated in the adoption of two austerity packages in 1995 and 1996 (Strukturanpassungsgesetze I \& II), which reduced the annual public deficit from 5.7 percent in 1995 to I.8 percent of GDP in 1997.

Immediately after the 1994 elections, the grand coalition pursued a unilateral reform strategy to facilitate the consolidation of public finances (' 52 points programme'). For the first time in Austrian post-war history, the social partners were not formally involved in the policy-making process. Yet, when rising tensions between and inside the coalition partners around the design of cost containment measures emerged, the new party chair of the ÖVP, Wolfgang Schüssel, broke off the budget negotiations with no result and called for new elections. The subsequent election campaign took place against the backdrop of two diverging approaches to the problem of reducing public debt: a fifty-fifty ratio of revenue increases and spending cuts (SPÖ) versus spending cuts (ÖVP). Judging from the election outcome, the approach of the SPÖ proved more popular than the fiscal retrenchment campaign of the ÖVP (Wagschal/ Wenzelburger 2008, I04). The 1995 elections extended the share of the SPÖ to 38 percent (+ 3 percent), while the ÖVP remained the second strongest party with 28.3 percent (+o.6 percent). The coalition negotiations between the two major parties reflected the power-conscious party leadership of Schüssel: the ÖVP could either form a coalition with the FPÖ or go into opposition, while the only option left for the SPÖ to remain in office was the formation of another grand coalition. Reflecting their bargaining position, the ÖVP made government participation conditional on the adoption of a savings volume of Ioo billion ATS for the next two years - with success. The subsequent formation of another grand coalition in I995 paved the way for the proposal of a second austerity package (Strukturanpassungsgesetz II) to meet the Maastricht convergence criteria.

Well aware of the electoral dangers of ongoing conflict and another reform deadlock, the government delegated pre-negotiations about the design of the austerity package II to the social partners. The subsequent 
compromise between the ÖGB and the WKÖ played an important role in mitigating political conflicts between the grand coalition partners: "With the savings package the social partners proved that they were able to perform their function of "easing the burden of the state" in a very thorough way' (Unger 2003, I07). Drawing on survey data and press coverages, Reinhard Heinisch notes that the Austrian populace came to trust the reform capacity of the social partners more than that of the grand coalition partners: 'The social partnership was seen as delivering an important public good by ensuring overall stability and by diluting painful economic medicine as much as possible - at a time when the government appeared increasingly less effective' (Heinisch 200I, 40).

It is clear that the welfare cuts of the austerity package II in the context of EMU adjustment were more beneficial to capital than to labour. But the principal aim of reducing public debt gave rise to successful attempts of the ÖGB to enforce its demand for an extension of the social insurance coverage (Tálos 1999, 274f.). For example, the austerity package II included the quasi-freelancers and the dependent self-employed into statutory pension, health and accident insurance. The SPÖ came to support the policy demands of the ÖGB, because the interest organisation of labour had a more informed view of atypical employment contracts than the party leaders. ${ }^{2}$ The Head of the ÖGB's labour market and education division, whom I interviewed, summarized the position of the unions toward the social protection of atypical employment contracts in the following terms: 'Atypical employment contracts became an essential question for us when we recognised that their rapid growth poses a massive threat to regular employment contracts. ${ }^{3}$

Comparing the politics of fiscal consolidation of nine countries in the late 1990s, Wagschal/Wenzelburger (2008) come to the conclusion that the reduction of public deficits through the second austerity package was based on 'a little bit of savings everywhere'. This assessment resonates in characterising the Austrian corporatist politics of small steps in hard times. Rather than seeking transformative change, the cooperation between the social partners reflects a consensual policymaking logic of incremental change. Following this pattern of adjustment, the interest organisations of labour remained sufficiently influential to prevent any largescale retrenchment initiatives. The final settlement contained in the second austerity package reflected a compromise between the balanced approach of the SPÖ and the cutback agenda of the ÖVP. ${ }^{4}$

2 Interview with Eleonora Hostasch, Minister of Labour Market, Health Care, and Social Affairs of the SPÖ (1997-2000), 27th January 2015 .

3 Interview with Alexander Prischl, Head of Labour Market and Education Division of the ÖGB, 5th March 2015.

4 Consisting of a ratio of one third of revenue increases and two thirds of expenditure cuts, the final bill affected different social
In the years to come, union influence faced mounting pressure from political forces rather than economic adjustment constraints. From the perspective of prominent representatives of the ÖVP, the power resources of organised labour blocked competitiveness-enhancing policy innovation. In particular, the veto power of the ÖGB under SPÖ-led grand coalitions led to the strategic understanding of Wolfgang Schüssel and his chief ideologue, Andreas Khol, that the disempowerment of organised labour had become imperative for the accomplishment of an economic paradigm change (Khol 200I, 209f.). At the same time, the rise of the FPÖ under its charismatic leader Jörg Haider opened up a potential coalition partner that shared the critical stance of the ÖVP against union influence on public policy. Eventually, the FPÖ became the second strongest party in the 1999 elections (26.9 percent; +5 percent) at the expense of the ÖVP (26.9 percent; -I.4 percent), while the SPÖ took the largest vote share in spite of losses (33.2 percent; -4.9 percent). Once again, the strongest party, the SPÖ, invited the ÖVP to form a grand coalition. Unlike in 1995, the failed coalition negotiations between the SPÖ and ÖVP paved the way for the formation of a centre-right coalition that aimed at the break with the consensus-oriented past of Austrian social partnership.

The ÖVP-FPÖ coalition started out as an ideologically cohesive and united front that pushed through a remarkable series of reforms from the beginning of 2000 . Cost containment and deregulation were the prime cornerstones of the government's economic agenda. To implement this agenda, the government had to rely on its parliamentary majority and suspend the corporatist logic of union involvement in public policy (Obinger/ Tálos 2006). In late 2000, the government unilaterally legislated the following labour market policy changes: a reduction in the family surcharge and in federal contributions to labour market policy; a reduction of the basic replacement rate from 57 percent to 55 percent; an extension of the qualifying period from 26 to 28 weeks, and; the freezing of benefit indexation as well as tightened sanctions (Fink 2006, I8I).

However, the government's reform zeal came under strain from intra-coalitional divisions in 200I. Election losses at the regional level in tandem with the ÖVP's neoliberal agenda prompted growing opposition from the employees' wing of the FPÖ against welfare state retrenchment (Müller/Fallend 2004, 825). Their fear was that another series of ÖVP-led neoliberal reform initiatives would cause further disaffection among blue-

groups in bearing the costs of fiscal adjustment. In the words of Helmut Kramer, Head of the Austrian Institute of Economic Research (WIFO), on the design of the second austerity package: 'This time it is noticeable that this package - I am almost inclined to say primarily - makes the higher earners foot the bill' (Wirtschaftswoche 08.02.1996). 
collar workers, a group that had turned into an electoral stronghold of the FPÖ during the I990s (Luther 2003). In an interview with the author, Andreas Khol highlighted the veto of Herbert Haupt, the FPÖ's Minister of Social Affairs, as a source of reform deadlocks in labour market issues. ${ }^{5}$

The politics behind the homogenisation of the severance pay scheme, the Abfertigung neu, reveal a great deal about the intra-coalitional tensions that ruled out a unilateral reform strategy in the area of labour market policy. By mid-200I, the ÖVP-FPÖ government announced it would transform the severance payment scheme into an occupational pension pillar alongside the statutory public pension insurance - a hot-button issue for organised labour. The old severance pay scheme was the subject of broad criticism for its supposed detrimental impact on labour market mobility and the requirement that the employee be formally dismissed by the employer (EIRO 200I). As eligibility for severance pay required employees to work for three years for one employer and refrain from a notice of employment resignation, the old scheme provided very generous payments for insiders of the private sector with continuous employment biographies. ${ }^{6}$ In fact, only 15 percent of annual contract dissolutions led to severance pay entitlements (Obinger/ Tálos 2006, 9I).

Yet, internal disputes over the minimum duration of employment for entitlement to the accumulation of severance pay marred the autonomous reform capacity of the ÖVP-FPÖ government (EIRO 2002). The ÖVP under Schüssel demanded strict adherence to the government programme, according to which entitlement to severance pay should require one year of employment (Wiener Zeitung, 23.5.200I). In contrast, the FPÖ contended for entitlement to severance pay from the first day of employment onwards. The centre-left opposition and the ÖGB shared the position of the FPÖ. In addition, the ÖVP and WKÖ vigorously opposed the FPÖ's demand for an entitlement for cases of contract dissolutions by employees (ibid.).

When the controversial negotiations between the coalition partners appeared to become deadlocked, the ÖVP-FPÖ government delegated the issue to the social partners (Pernicka 2003). In the words of a senior official in the Ministry of Labour Market and Social Affairs, who was involved in the reform process: 'The ÖVP and

5 Interview with Andreas Khol, Party Whip of the ÖVP (1994-I999, 2000-2002), 9th December 20I4. Unfortunately, I was not able to reach Herbert Haupt for an interview to cross-validate the descriptions provided by Andreas Khol.

6 The level of severance payment amounted to two months of the gross wage after three years of service; three months of the gross wage after five years of service; four months after Io years; six months after I 5 years; 9 months after 20 years; and I2 months after 25 years. The severance pay was subject to a flat-rate income tax of 6 percent.
FPÖ did not manage to find an agreement on the basis of the government programme. In response, both parties agreed to delegate the Abfertigung neu to the social partners, which developed the so-called I4 cornerstones of the subsequent reform.' 7

This party-political reform deadlock forms one necessary condition for the subsequent policy solution. Another part of the explanation comes from encompassing representational union interests. Since the late I990s, the BAK and ÖGB demanded an extension of the coverage of the insider-oriented severance pay scheme to the whole workforce (EIRO 20OI). After long-standing negotiations, the social partners jointly proposed a new scheme, which entitled all private sector employees to accumulate individual savings from the first day of employment onwards and across different employment relationships over time. In return, the WKÖ could reduce non-wage labour costs for severance pay provisions through the stipulation of an employer's contribution rate of 1.53 percent of the gross monthly wage. Unlike the Continental European trend of dualization in job security regulations, Austria unified the conditions of severance payment in favour of discontinuous employment biographies.

In a similar vein, the FPÖ blocked the ÖVP in the area of eligibility conditions for the long-term unemployed. Similar to the German Hartz IV legislation, in their 2000 and 2003 government programmes, the Austrian centre-right government announced to introduce an obligation to work in return for continued benefit receipt and state-financed pay top-ups ('I-Euro jobs'). Asked about why the government did not implement its government programme in this aspect, Khol responded that the FPÖ came to block it. ${ }^{8}$ His description about the veto of the FPÖ under Haupt was confirmed by the Head of Department for Labour Market Policy in the Ministry of Social Affairs. ${ }^{9}$ Instead of pursuing a unilateral approach, the government invited the social partners to develop changes for the regulation of the unemployment benefit entitlement (Afonso 2013, I63f.).

The ÖVP and the WKÖ had a common agenda in that they demanded (i) a broadened definition of the kind of jobs that are deemed suitable (Zumutbarkeitsbestimmungen) and (ii) the removal of 'occupational protection' for job seekers with specific skills (Berufsschutz). According to this agenda, the Public Employment Service would have been able to require the unemployed to take up more types of jobs over longer travel distances.

7 Interview with senior official in the Ministry of Labour Market and Social Affairs, 29th May 2015.

8 Interview with Andreas Khol, Party Whip of the ÖVP (I994-I999, 2000-2002), 9th December 2014.

9 Interview with Stefan Potmesil, Head of Labour Market Department in the Ministry of Social Affairs (2000-2010), 27th August 2015 . 
To achieve support for this approach, organised labour received two concessions (ibid.). First, the occupational protection remained in place for a shortened duration of Ioo days. Second, the package included the introduction of a 'wage guarantee'; that is, a guarantee that the wage level of a proposed job corresponds at least to a certain percentage of the previous job. As a result, a job may be deemed suitable if its related wage amounted to not less than 80 percent of the previous job during the first 120 days of unemployment or 75 percent during the end of the benefit entitlement period. Instead, part-time workers received a wage guarantee of Ioo percent for every proposed job placement.

The 'black-blue' era ended with the 2006 elections. Somewhat surprisingly, the SPÖ won the elections with slight losses (-I.2 percent) despite the collapse of an ÖGB-led 'red' bank (BAWAG) in the wake of failed speculative transactions. On the other hand, the ÖVP lost a whole 8 percent, whereas the new party of Jörg Haider, the BZÖ, managed to gain entry into parliament (4.I percent). Eventually, it took the SPÖ more than four months to reach a coalition agreement with the ÖVP in order to form another grand coalition.

The policy performance of the grand coalition since 2007 powerfully demonstrates that union influence may increase under favourable party-political conditions. Announcing to (re-)involve the peak level associations in virtually all areas of economic and social policy, the government programme of 2007 mentions 'the social partners' no less than 2I times (Tálos 2008). Unlike the politics of EMU adjustment during the I990s, the grand coalition did not set strict policy guidelines along which the social partners helped formulate reforms to consolidate the federal budget. On the contrary, economic growth rates at the level of 3.5 percent/GDP (2006/07) facilitated the maintenance of sound public finances until the onset of the Great Recession.

The return of the SPÖ to office under Alfred Gusenbauer was one obvious reason for increasing union influence. In fact, however, the grand coalition as a whole benefited from corporatist concertation through the problem-solving capacity of the social partners. During the period of uncertainty that followed the 2006 elections, the interest organisations of labour successfully attempted to find agreement with the WKÖ on a number of policy areas to pre-empt the emergence of unilateral reform proposals (Afonso 2013, I7If.). One central lesson of the previous ÖVP-FPÖ government was that the viability of union influence might require the occupation of policy issues in uncertain times. In addition to the proactive strategy of the social partners, the subsequent grand coalition faced difficulties in finding policy compromises. Mutual reform blockages and open confrontations between the coalition partners created tensions that culminated in the call for fresh elections after only one and a half years in office. The interest organisations of labour, however, had an interest in maintaining the grand coalition to perpetuate their influence through the SPÖ's participation in the ruling coalition. High reform activity in spite of intra-coalitional divisions suggests the social partners' stabilising effect on the reform capacity of the government. Indeed, as Emmerich Tálos finds (2008, ch. 5), the national peak level associations somewhat offset the government's difficulties in carving out policies by playing a pivotal role in the preparation of government reforms.

The result of this power-distributional configuration - union influence due to a 'weak' SPÖ-led grand coalition - was a series of political exchanges that expanded the protection of outsiders in return for tightened activation demands. Proof of this exchange came in the amendment of the unemployment insurance law in 2007, which legislated an extension in the coverage of the unemployment insurance and educational leave in return for tightened eligibility conditions through longer travel distances and availability requirements $(\mathrm{Ob}-$ inger et al. 2012, 184). Asked about why the ÖGB prioritised the expansion of labour and social rights to atypical forms of employment, the Head of the ÖGB's labour market and education division, responded,

Some employers say: 'You can either work for me as a freelancer or as a new self-employed. Full stop.' What should I do in case I am unemployed? Then I will prefer an offer like this over having nothing. And once I am employed under these conditions, it's hard to re-gain a regular contract. This is a development we had discovered and we wanted to address. Not because we are the mere representatives of the new self-employed, but rather because we see that these types of contracts lead to a general decline of regular jobs in regular work sectors. ${ }^{\text {IO }}$

The 2008 elections, which occurred in the wake of internal conflicts, led to the formation of another grand coalition. Immediately after taking office, the SPÖ-ÖVP government under Werner Faymann invited the social partners to design a tripartite policy response to the onset of the Great Recession. Faced with a severe GDP contraction of almost 4 percent in 2009, the three actors were quick to find a consensus around a series of policy changes aimed at: (i) the stabilisation of employment and (ii) re-integration of people out of work. Perhaps the most prominent change was the extension of shorttime work, first to 18 and then 24 months. This was tailored to similar measures in Germany, given Austria's strong trade relationship with its larger neighbouring

Io Interview with Alexander Prischl, Head of Labour Market and Education Division of ÖGB, 5th March 2015. 
country, especially in automobile production. Overall, the short-time work strategy was considered effective in retaining qualified staff, thereby mitigating the corrosive effects of the Great Recession on employment levels.

In addition to the short-time work extension, the policy response to the Great Recession included an expansion of training arrangements such as labour foundations in tandem with eased access to partial retirement. To finance these changes, the grand coalition increased ALMP spending by $€ 400$ million (44 percent) in 2009 (Atzmüller/Krenn/Papouschek 2012, 27f.). As a result, in 2010 and 20II, Austria achieved the third and fourth highest ALMP expenditure rates, respectively, in proportion to the unemployment rate and GDP in the OECD (BMASK 2012, 2OI3). Further upskilling investments came into force in 20I3: the qualified employees' grant (Fachkräftestipendium) and educational part-time work (Bildungsteilzeit) (EIRO 2OI3). The former eases access conditions on re-training for low-skilled employed and unemployed workers. The latter addresses employed workers who pursue a reduction in working time to attend training activities by offering a monetary compensation for wage losses. Overall, the labour market policy response to the crisis thus simultaneously involved both instruments to keep existing jobs (e.g. short-time work) and combat unemployment (e.g. training) while refraining from benefit cuts for people out of work at the same time.

\section{Conclusion}

The case of Austria illuminates two points about the politics of labour market policy in the era of liberalisation. First, where unions are united, they are able to support the social demands of outsiders. The virtue of labour unity is that it gives voice to member unions, which are hit hardest by the low-wage competition from atypical employment contracts. This institutionalised hierarchy of the ÖGB sets Austrian unionism apart from the classical sectoral model of German unionism. Another factor that deserves attention is the role the WKÖ played in maintaining cooperative relations with the ÖGB. The principle of mandatory membership was undeniably central to its commitment to the 'social partnership'. This institutional compulsion on employers implied that small firm owners could not defect from corporatist arrangements in favour of a market-clearing adjustment strategy at the firm level. It therefore ruled out the full neoliberal reorientation characteristic of business associations in countries with similar corporatist legacies (Paster 2OI3). Unlike the ÖGB, however, the firstorder priority of the WKÖ was reducing labour costs and reservation wages to the detriment of outsiders.
Second, however, the causal significance of union preferences is not determinative. On the contrary, a decline of the workforce that is unionised in an age of capital liberalisation might well legitimise a unilateral reform strategy that excludes the preferences of unions from the policy-making process (Culpepper/Regan 20I4, Hassel 2015). That a united majority allows governments to override union confederations was powerfully demonstrated by the policy performance of the ÖVP-FPÖ coalition (Obinger/Tálos 2006). In 2003, for example, the FPÖ supported the ÖVP in imposing a unilateral pension reform on organised labour, because cost savings in the public pension system formed an important part of its electoral claim to put an end to the accumulation of public debt (Müller/Fallend 2004). This common agenda explains why the ÖVP-FPÖ coalition was strong enough to refrain from labour acquiescence in the 2003 pension reform. In the area of labour market policy, however, the ÖGB remained influential enough to receive concessions over virtually the entire period of investigation. The question is, why?

This article attributed the persistence of union influence to the inability of Austrian governments to find a durable consensus independent from the problemsolving capacity of a labour-inclusive 'social partnership. When governments are not sufficiently united to act unilaterally in the policy-making process, they cannot fend off the political demands from others. They instead reach out to trade unions, because social partner negotiations provide them with an extra-parliamentary channel of consensus mobilisation. This weakness best explains why Austrian governments pursued a labourinclusive reform strategy despite fiscal constraints (1990s), neoliberal policy platforms (2000-2006) and the onset of the great recession (post-2008 years) in an age of declining union power. The political choice of weak governments to share policy-making authority with organised interests provides trade unions with the opportunity to resist increased inequality in employment and welfare standards. When that political choice shifts to a unilateral reform strategy, the result excludes that opportunity to the detriment of atypically employed and unemployed workers.

\section{Literature}

Afonso, Alexandre (2013). Social Concertation in Times of Austerity: European Integration and the Politics of Labour Market Reforms in Austria and Switzerland, Amsterdam.

Atzmüller, Roland/Manfred Krenn/Ulrike Papouschek (2012). Innere Aushöhlung und Fragmentierung des österreichischen Modells: Zur Entwicklung von Erwerbslosigkeit, prekärer Beschäftigung und Arbe- 
itsmarktpolitik, in: Karin Scherschel/Peter Streckeisen/ Manfred Krenn (Hg.): Neue Prekarität: Die Folgen aktivierender Arbeitsmarktpolitik - europäische Länder im Vergleich, Frankfurt/New York, 75-IIO.

Baccaro, Lucio/Sang-Hoon Lim (2007). Social Pacts as Coalitions of the Weak and the Moderate, in: European Journal of Industrial Relations, Vol. I3(I), 27-46.

Baccaro, Lucio/Marco Simoni (2008): Policy Concertation in Europe: Explaining Government's Choice, in: Comparative Political Studies, Vol. 4I(IO), I323-I348.

Baccaro, Lucio/Chris Howell (2OII). A Common Neoliberal Trajectory: The Transformation of Industrial Relations in Advanced Capitalism, in: Politics \& Society, Vol. 39(4), 52I-563.

Bundesministerium für Arbeit, Soziales und Konsumentenschutz (2012). Aktive Arbeitsmarktpolitik in Österreich. Internet: http://www.ams.at/_docs/ooI_Aktive_Arbeitsmarktpolitik.pdf

Bundesministerium für Arbeit, Soziales und Konsumentenschutz (20I3). Aktive Arbeitsmarktpolitik in Österreich. Internet: http://www.sozialministerium.at/cms/site/ attachments/2/7/9/CH2 I 24/CMSI $249975678352 /$ doku_aamp_i994-20I3_webversion.pdf

Bock-Schappelwein, Julia/Ulrike Mühlberger (2008). Beschäftigungsformen in Österreich: Rechtliche und quantitative Aspekte, WIFO Monatsbericht, Austrian Economic Research Institute, Wien.

Clegg, Daniel (2012). Solidarity or Dualization? Social Governance, Union Preferences and Unemployment Benefit Adjustment in Belgium and France, in: Patrick Emmenegger/Silja Häusermann/Bruno Palier/Martin Seeleib-Kaiser (Hg.): The Age of Dualization: The Changing Face of Inequality, Oxford, 253-276.

Culpepper, Pepper D./Aidan Regan (2014). Why Don't Governments Need Trade Unions Anymore? The Death of Social Pacts in Ireland and Italy, in: Socio-Economic Review, Vol. I2(4), 723-745.

Eichhorst, Werner/Paul Marx (2012). Whatever Works: Dualization and the Service Economy in Bismarckian Welfare States, in: Patrick Emmenegger/Silja Häusermann/Bruno Palier/Martin Seeleib-Kaiser (Hg.): The Age of Dualization: The Changing Face of Inequality, Oxford, 73-99.

European Industrial Relations Observatory (200I). Reform of Severance Pay under Discussion, 27.06.200I. Internet: http://eurofound.europa.eu/observatories/ eurwork/articles/reform-of-severance-pay-underdiscussion (Last accessed at March I5, 2017).

European Industrial Relations Observatory (2002). Social Partners Agree Far-Reaching Reform of Severance Pay, I8.I2.200I. Internet: http://www.eurofound.europa.eu/eiro/200I/I2/feature/atori223If.htm (Last accessed at March I5, 20I7).

European Industrial Relations Observatory (2007). Social Partners Tackle Unemployment and Skills Deficit,
2I.I2.2007. Internet: http://www.eurofound.europa. eu/eiro/2007/II/articles/ato7IIO39i.htm (Last accessed at March I5, 2017).

Fallend, Franz (2006). Die ÖVP, in: Emmerich Tálos/Marcel Fink (Hg.): Schwarz-Blau: Eine Bilanz des „NeuRegierens", Wien, 3-I8.

Fervers, Lukas/Hannah Schwander (2015). Are Outsiders Equally Out Everywhere? The Economic Disadvantage of Outsiders in Cross-National Perspective, in: European Journal of Industrial Relations, Vol. 2I(4), 369-387.

Fink, Marcel (2006). Zwischen „Beschäftigungsrekord” und „Rekordarbeitslosigkeit”: Arbeitsmarkt und Arbeitsmarktpolitik unter Schwarz-Blau/Orange, in: Emmerich Tálos/Marcel Fink (Hg.): Schwarz-Blau: Eine Bilanz des „Neu-Regierens“, Wien, I70-I87.

Fink, Marcel/Manfred Krenn (20I4). Prekariat und Working Poor: Zum Verhältnis von Erwerbsarbeit und sozialer Inklusion in Österreich, in: Nikolaus Dimmel/Martin Schenk/Christine Stelzer-Orthofer (Hg.): Handbuch Armut in Österreich, 2. Aufl., Wien.

Hassel, Anke (2014). The Paradox of Liberalization: Understanding Dualism and the Recovery of the German Political Economy, in: British Journal of Industrial Relations, Vol. 52(I), 57-8I.

Hassel, Anke (2015). Trade Unions and the Future of Democratic Capitalism, in: Pablo Beramendi/Silja Häusermann/Herbert Kitschelt/Hanspeter Kriesi (Hg.): The Politics of Advanced Capitalism, Cambridge.

Heinisch, Reinhard (2000). Coping with Economic Integration: Corporatist Strategies in Germany and Austria in the I990s, in: West European Politics, Vol. 23(3), 67-96.

Heinisch, Reinhard (200I). Defying Neoliberal Convergence: Austria's successful Supply-Side Corporatism in the I990s, in: Environment and Planning C: Government and Policy, Vol. 19(I), 29-44.

Iversen, Torben/Anne Wren (1998). Equality, Employment and Budgetary Constraint: The Trilemma of the Service Economy, in: World Politics, Vol. 50(4), 507-546.

Katzenstein, Peter J. (1984). Corporatism and Change. Austria, Switzerland and the Politics of Industry, Ithaca/New York.

Khol, Andreas (200I). Die Wende ist geglückt: Der schwarze-blaue Marsch durch die Wüste Gobi, Wien.

Knotz, Carlo/Johannes Lindvall (20I5). Coalitions and Compensation: The Case of Unemployment Benefit Duration, in: Comparative Political Studies, Vol. $48(5), 586-6 \mathrm{I} 5$.

Luther, Kurt (2003). The Self-Destruction of a RightWing Populist Party? The Austrian Parliamentary Election of 2002, in: West European Politics, Vol. 26(2), I36-I52. 
Müller, Wolfgang C./Franz Fallend (2004). Changing Patterns of Party Competition in Austria: From Multipolar to Bipolar System, in: West European Politics, Vol. 27(5), 80I-835.

Obinger, Herbert (2002). Veto Players, Political Parties and Welfare State Retrenchment, in: International Journal of Political Economy, Vol. 32 (2), 44-66.

Obinger, Herbert/Emmerich Tálos (2006). Sozialstaat Österreich zwischen Kontinuität und Umbau: Eine Bilanz der ÖVP/FPÖ/BZÖ-Regierung, Wiesbaden.

Obinger, Herbert/Peter Starke/Alexandra Kaasch (2012). Responses to Labor Market Divides in Small States Since the I990s, in: Patrick Emmenegger/Silja Häusermann/Bruno Palier/Martin Seeleib-Kaiser (Hg.): The Age of Dualization: The Changing Face of Inequality in Deindustrializing Countries, New York, 176-200.

Palier, Bruno/Kathleen Thelen (2010). Institutionalizing Dualism: Complementarities and Change in France and Germany, in: Politics \& Society, Vol. 38(I), II9I48.

Paster, Thomas (2013). Why Did Austrian Business Oppose Welfare Cuts? How the Organization of Interests Shapes Business Attitudes Toward Social Partnership, in: Comparative Political Studies, Vol. 47(7), 966-992.

Pernicka, Susanne (2003). Arbeitsbeziehungen nach der rechtskonservativen Wende: Sozialpartnerschaft in der Krise? In: Kurswechsel 3/2006, 84-87.

Rueda, David (2007). Social Democracy Inside Out: Government Partisanship, Insiders, and Outsiders in Industrialized Democracies, Oxford.

Scharpf, Fritz (200o). The Viability of Advanced Welfare States in the International Economy: Vulnerabilities and Options, in: Journal of European Public Policy, Vol. 7(2), 190-228.

Tálos, Emmerich (1999). Atypische Beschäftigung in Österreich, in: Ibid. (Hg.): Atypische Beschäftigung: Internationale Trends und sozialstaatliche Regelungen, Wien, 36-81.

Tálos, Emmerich/Bernhard Kittel (200I). Gesetzgebung in Österreich. Akteure, Netzwerke und Interaktionen in politischen Entscheidungsprozessen, Wien.

Tálos, Emmerich (2008). Sozialpartnerschaft: Ein zentraler politischer Gestaltungsfaktor in der Zweiten Republik, Innsbruck.

Thelen, Kathleen (2014). Varieties of Liberalization: The New Politics of Social Solidarity, New York.

Wagschal, Uwe/Georg Wenzelburger (2008). Haushaltskonsolidierung, Wiesbaden.

Unger, Brigitte (2003). Austrian Social Partnership. Just a Midlife Crisis? In: Frans van Waarden/Gerhard Lehmbruch (Hg.): Renegotiating the Welfare State: Flexible Adjustment through Corporatist Concertation, New York, 97-II4.

\section{Author}

Philip Rathgeb is a postdoctoral researcher at the Department of Politics and Public Administration at the University of Konstanz. His principal research areas are comparative political economy and welfare states. He earned his PhD from the Department of Political and Social Sciences at the European University Institute in September 2016. His doctoral research was awarded with the Theodor Körner Prize in honour of outstanding young academics in the areas of Law, Social Sciences, and Economics. 
